\title{
1. INTRODUCTION: SCIENTIFIC OBJECTIVES AND EXPLANATORY NOTES, DEEP SEA DRILLING PROJECT LEG 59
}

\author{
Shipboard Scientific Party
}

\section{SCIENTIFIC OBJECTIVES}

In the dynamics of sea-floor spreading and plate tectonics, one of the least understood relationships is that between subduction and the attendant formation of island arcs, back arcs, and back-arc basins. In the western Pacific, kinematic analysis of plate tectonics demonstrates that oceanic crust is being consumed in trenches at rates over $10 \mathrm{~cm}$ per year. Behind such trenches rise large, active, arcuate volcanic ridges. And beyond these ridges, one or more relatively narrow back-arc basins form-some of which are actively dilating to form basaltic crust reminiscent of deeper ocean basins; others are inactive, separated from active back-arc basins by submerged ridges, which presumably represent earlier stages of arc volcanism and back-arc basin spreading. Hypotheses on the origin of back-arc basins include entrapment of old oceanic crust during island-arc formation, generation of new crust by arc migration or transform faulting (sea-floor spreading), subsidence and foundering of continental or quasicontinental crust with attendant or subsequent "oceanization," modification of old sea floor by renewed volcanism, or a combination of some or all of these mechanisms.

In order to investigate the genesis of inter-arc and back-arc basins and related ridges, it is necessary to examine relationships between the age and composition of basement and the environment and history of marine sedimentation. Sedimentation history provides clues for evaluating times of uplift and subsidence and timing of major periods of arc volcanism evidenced by the presence of volcanic ash. Back-arc and inter-arc basins are similar in many respects to open-ocean basins, but they differ in size and depth relations and in subtle compositional basement characteristics that may be critical

\footnotetext{
${ }^{1}$ Loren Kroenke (Co-Chief Scientist), Hawaii Institute of Geophysics, University of Hawaii, Honolulu, Hawaii; Robert Scott (Co-Chief Scientist), Department of Geology, Texas A\&M University, College Station, Texas; Kathy Balshaw, Department of Geology, Rice University, Houston, Texas; Simon Brassell, School of Chemistry, University of Bristol, Bristol, United Kingdom; Pierre Chotin, Laboratoire de Géologie Structurale, Université Pierre et Marie Curie, Paris, France (now at: Département de Géologie, Universite Mohammed V, Rabat, Morocco); Mary E. Heiman, Stratigraphy Laboratory, Mobil Oil Company, Dallas, Texas (now at: F and H Biostratigraphic Associates, Laramie, Wyoming); Teruaki Dallas, Texas (now at: $\mathrm{F}$ and $\mathrm{H}$ Biostratigraphic Associates, Laramie, Wyoming); Teruaki
Ishii, Ocean Research Institute, University of Tokyo, Tokyo, Japan; Barbara H. Keating, Hawaii Institute of Geophysics, University of Hawaii, Honolulu, Hawaii; Erlend Martini, Geologisch-Palaontologisches Institut, Johann-Wolfgang-Goethe-Universität, Frankfurt am Main, Federal Republic of Germany; David P. Mattey, Department of Geology, Bedford College, University of London, London, United Kingdom (now at: Department of Geological Sciences, University of Birmingham, Birmingham, England); Kelvin Rodolfo, Department of Geological Sciences, University of Illinois, Chicago, Illinois; Renzo Sartori, Laboratorio di Geologia Marina del C.N.R., Bologna, Italy; Fritz Theyer, Hawaii Institute of Geophysics, University of Hawaii, Honolulu, Hawaii; John L. Usher, Deep Sea Drilling Project, Scripps Institution of Oceanography, La Jolla, California; and Guram Zakariadze, Institute of Geology, Georgian Academy of Sciences, Tbilisi, U.S.S.R. (now at: V. I. Vernadsky Inst. of Geochem. and Analyt. Chem., U.S.S.R. Acad. of Sciences, Vorobyewskoe chaussee 47A, 117334 Moscow, U.S.S.R.).
}

in evaluating the origin and tectonic significance of ophiolites, island-arc tholeiites, and Archean greenstone belts. Studies of basement age and composition are thus directed toward distinguishing between the formative processes of back-arc basin crust and those of normal ocean crust.

Of numerous island-arc systems in the western Pacific, the Mariana arc-trench system and the basins and submerged ridges lying west of them in the Philippine Sea were studied because they seemed best suited to answer questions regarding arc-trench and back-arc basin formation. Three years of planning by the JOIDES Active Margin Panel, Ocean Crust Panel, and Planning Committee resulted in a proposed transect of drill sites aligned more or less along the 18th parallel. This South Philippine Sea transect was designed to investigate each major basin and ridge between the central part of the West Philippine Sea and the Mariana Trench and the Pacific Ocean plate immediately to the east. DSDP Legs 59 and 60 were designated to undertake the study; the drilling program was conducted during the period February 3 through May 15, 1978. Figure 1 shows the location of the drill sites; the Leg 59 drilling program comprised Sites 447 through 451 and the Leg 60 program Sites 452 through 461 .

\section{EXPLANATORY NOTES}

\section{Organization of the Volume}

The volume is divided into three parts. Part I discusses the overall aims of the cruise and reports on the operations and scientific findings at the five Leg 59 sites. Part II presents detailed discussions of scientific studies undertaken after the cruise by members of the shipboard scientific party and shore-based participants; this material covers the subjects of geophysics and tectonics, paleontology, sedimentology, and geochemistry and petrology. Part III integrates and summarizes the results of Leg 59 and presents the conclusions that have been drawn.

\section{Authorship}

Authorship of the site chapters (447-451, Chapters 2-6) is that of the collective shipboard scientific party; the ultimate responsibility for the organization and integration of this material lies with the co-chief scientists. These five chapters (whose primary authorship is indicated within parentheses) all follow this general outline:

Site Summary Data and Principal Results (Kroenke, Scott, and Usher)

Background and Objectives (Kroenke and Scott) 


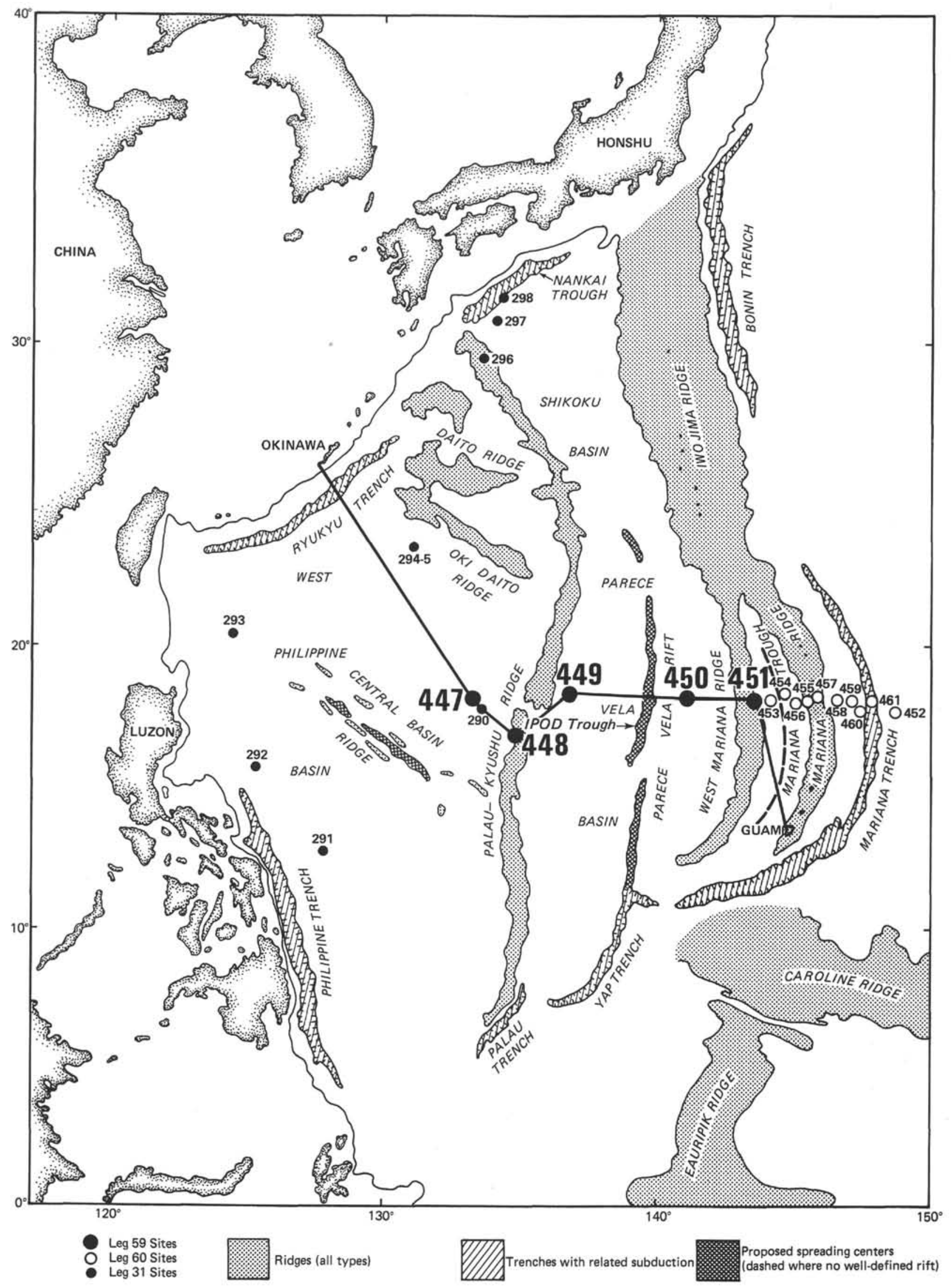

Figure 1. Site locations for Legs 59, 60, and 31. 
Operations (Foss ${ }^{2}$ and Usher)

Sedimentary Lithology (Rodolfo, Sartori, and Balshaw)

Biostratigraphy (Martini, Heiman, and Theyer)

Accumulation Rates (Theyer and Rodolfo)

Organic Geochemistry (Brassell)

Igneous Petrography (Scott, Zakariadze, Mattey, and Ishii)

Paleomagnetism (Keating)

Physical Properties (Chotin and Kroenke)

Geophysics (Kroenke)

Summary and Conclusions (Kroenke and Scott)

\section{Survey and Drilling Data}

The selected critical survey data used for specific site selections are given in each site chapter. En route between sites, continuous observations were made of depth, magnetic field, and sub-bottom structure. Before dropping the beacon, short surveys were made on the Glomar Challenger using a precision echo sounder, seismic profiles, and magnetometer. Underway depths were continuously recorded on an EDO $3.5 \mathrm{kHz}$ precision depth recorder (PDR), based on an assumed 1500 $\mathrm{m} / \mathrm{s}$ sound velocity. The seismic profiles were obtained using two Bolt airguns, Teledyne hydrophone array, Bolt amplifiers and filters, and two EDO recorders.

The PDR depth (in m) at each site was corrected for (1) changes in the velocity of sound in sea water according to the tables of Matthews (1939) and (2) the depth of the hull transducer $(6 \mathrm{~m})$ below sea level. In addition, depths referred to the drilling platform were calculated on the assumption that this level is 10 meters above the water line.

All of these data are stored at the Deep Sea Drilling Project; copies of them, on $35 \mathrm{~mm}$ microfilm, may be obtained from the Data Archivist, Deep Sea Drilling Project, A-031, Scripps Institution of Oceanography, University of California at San Diego, La Jolla, California 92093. Only those portions of the data pertinent to immediate site selection and drilling objectives are used in this volume.

\section{Drilling Characteristics}

Because the water circulation down the hole is an open one, cuttings and broken pieces of core are lost to the sea and cannot be examined. Where this loss is excessive, i.e., zones of low or zero recovery, the only information on the materials being drilled is the rate of penetration, because no holes were logged on Leg 59 . This rate is not only a function of the physical properties of the material being drilled but is also a function of other variables, including bit weight and drill rpm as recorded on the drilling recorder. Thus the inferred lithostratigraphic column encompassing recovered rocks and intervening voids is based on the drilling characteristics, primarily penetration rate. These data are only partially reported in this volume; the remainder are stored at the

\footnotetext{
${ }^{2}$ Mr. Glenn Foss was Operations Manager aboard ship on Leg 59 . He contributed substantially to the writing of this part of each site chapter.
}

DSDP and may be obtained upon request at the address just noted.

When cores are split, many show signs of the sediment having been disturbed since its deposition. Such signs are the concave downward appearance of what originally were plane bands, the haphazard mixing of lumps of different lithologies, and the near fluid state of some sediments recovered from tens or hundreds of meters below the sea bed. It seems reasonable to suppose that these disturbances came about during or after the drilling of the core. Three different stages during which the core may suffer stresses sufficient to alter its physical characteristics from those of the in situ state are: drilling, retrieval (with accompanying changes in pressure and temperature), and core handling.

\section{Shipboard Scientific Procedures}

\section{Numbering of Sites, Holes, Cores and Samples}

DSDP sites are numbered consecutively from the first site drilled by the Glomar Challenger in 1968. Site numbers are thus unique. A site number refers to one or more holes drilled while the ship is positioned over one acoustic beacon. These holes may be located within a radius as great as 900 meters from the beacon. Several holes may be drilled at a single site by pulling the drill string above the sea floor ("mudline"), i.e., out of the hole, and offsetting the ship 100 meters or more to begin drilling another hole.

The first (or only) hole drilled at a site takes the site number. A letter suffix distinguishes each additional hole at the same site. For example: the first hole takes only the site number; the second takes the site number with suffix A; the third takes the site number with suffix B, and so forth. For sampling purposes, it is important to distinguish the holes drilled at a site, because recovered sediments or rocks from different holes usually do not come from equivalent positions in the stratigraphic column.

The cored interval is measured in meters below the sea floor. The depth interval of an individual core is the depth below the sea floor at which the coring operation began to the depth at which the coring operation ended. Each coring interval is generally 9.5 meters long, which is the nominal length of a core barrel; however, the coring interval may be shorter or longer (which is rare). "Cored intervals" are not necessarily adjacent to each other but may be separated by "drilled intervals." In soft sediment, the drill string may be "washed ahead" with the core barrel in place (but not recovering sediment) by pumping water down the pipe at high pressure to wash the sediment out of the way of the bit and up the space between the drill pipe and wall of the hole. If thin hard-rock layers are present, however, then it is possible to get "spotty" sampling of these resistant layers within the washed interval, and thus a cored interval may be greater than 9.5 meters.

Cores taken from a hole are numbered serially from the top of the hole downward. Core numbers and their associated cored interval in meters below the sea floor 
are unique for a hole and are entered into the DSDP computer data base.

Full recovery for a single core is normally 9.28 meters of sediment or rock, which is in a plastic liner $(6.6 \mathrm{~cm}$ in diameter), plus about a 0.2 -meter-long sample (without a plastic liner) in the core catcher. The core catcher is a device at the bottom of the core barrel that keeps the cored sample from sliding out when the barrel is being retrieved from the hole. The sediment-core, which is in the plastic liner, is then cut into 1.5 -meter-long sections and numbered serially from the top of the sediment core (Fig. 2). When full recovery is obtained, the sections are numbered from 1 through 7 , with the last section being shorter than 1.5 meters. The core-catcher sample is placed beneath the last section when the core is described and labeled core catcher (CC); it is treated as a separate section. ${ }^{3}$

When recovery is less than $100 \%$, and if the sediment or rock is contiguous, the recovered sediment is placed in the top ${ }^{4}$ of the cored interval; 1.5 -meter-long sections are then numbered serially, starting with Section 1 at the top. There will be as many sections as needed to accommodate the length of the core recovered (Fig. 2); for example, 3 meters of core in plastic liners will be divided into two 1.5-meter-long sections. Sections are cut start-

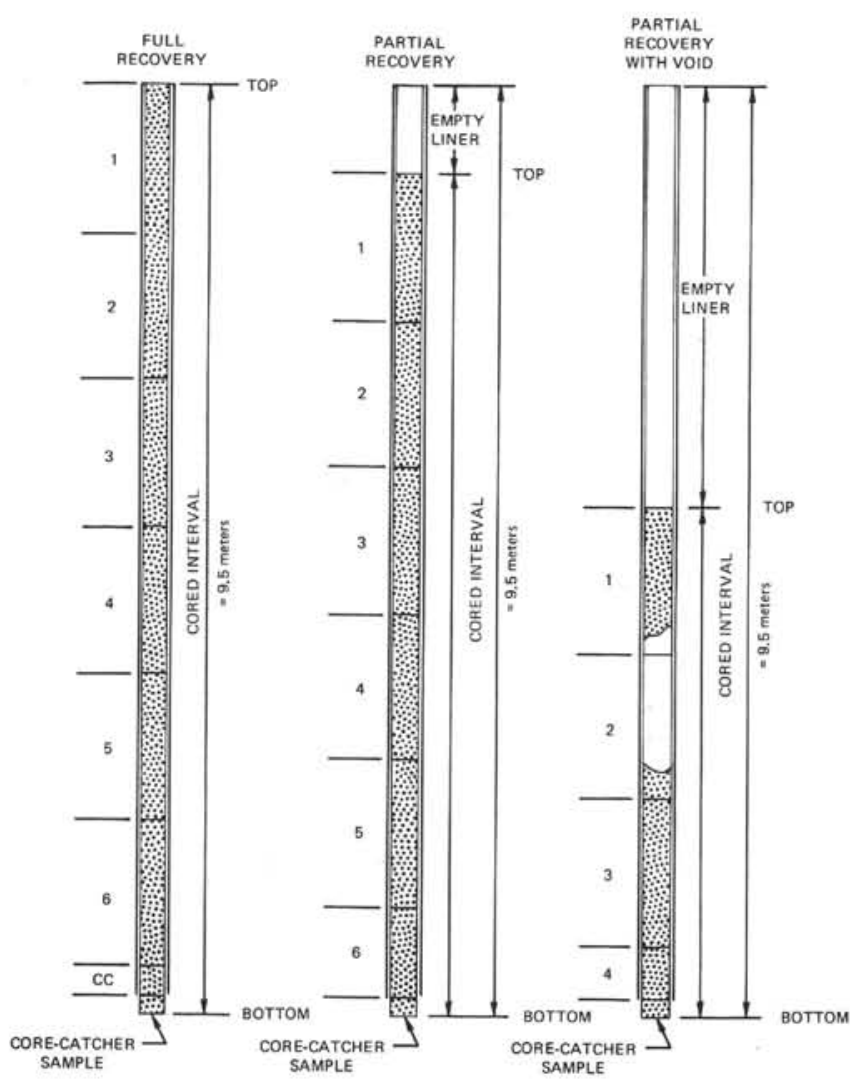

Figure 2. Labeling of core sections for various kinds of recovery.

\footnotetext{
${ }^{3}$ This procedure is followed for sediments only. For igneous rocks the core-catcher sample is incorporated into and given the number of the last section.

4 This technique differs from the labeling systems used on Legs 1 through 45 , which have a designation called "zero section" but do not have a "number 7 section."
}

ing at the top of the recovered sediment, and the last section may be shorter than the normal 1.5-meter length. Although the original stratigraphic position of the sediment in the cored interval is unknown when recovery is less than $100 \%$, we conventionally assign the top of the sediment recovered to the top of the cored interval for convenience in data handling and consistency. If recovery is less than $100 \%$ and core fragments are separated (and if shipboard scientists believe the sediment was not contiguous), then sections are numbered serially and the intervening sections are noted as void, whether they are contiguous or not.

Samples are designated by centimeter distances from the top of each section to the top and bottom of the sample in that section. A full identification number for a sample consists of the following information: leg, site, hole, core number, and interval in centimeters from the top of the section. For example, a sample identification number of $59-447 \mathrm{~A}-9-3,12-14 \mathrm{~cm}$ is interpreted as follows: 12 to $14 \mathrm{~cm}$ designates a sample taken at 12 to $14 \mathrm{~cm}$ from the top of Section 3 of Core 9, from the second hole drilled at Site 447 during Leg 59. A sample from the core catcher of this core is designated as 59-447A-9, CC.

The depth below the sea floor to the top of a sample numbered $59-447 \mathrm{~A}-9-3,12-14 \mathrm{~cm}$, is the summation of the following: (1) the depth to the top of the cored interval for Core 9, which is 76.0 meters; (2) plus 3 meters for Sections 1 and 2 (each $1.5 \mathrm{~m}$ long); (3) plus the $12 \mathrm{~cm}$ depth below the top of Section 3. All of these variables add up to 79.12 meters, which theoretically is the sample's depth below the sea floor.

\section{Handling of Cores}

The first assessment of the core material is made by paleontologists on core-catcher samples. After core is cut into 1.5-meter sections, sealed, and labeled, the sections are brought into the core laboratory for processing. The following determinations normally are made before the sections are split: gas analysis and continuous wet-bulk density determinations using the Gamma Ray Attenuation Porosity Evaluation (GRAPE).

The cores are then split longitudinally into "working" and "archive" halves. The archive half is described and photographed both in black and white and in color, but not sampled. Samples are then extracted from the "working" half, including, in the case of sedimentary lithologies, those for determination of grain-size distribution, mineralogy by X-ray diffractions, sonic velocity by the Hamilton Frame method, wet-bulk density by the static GRAPE technique, watercontent porosity, wet-bulk density by gravimetric analysis, carbon/carbonate analysis, paleontological studies, and magnetic studies. Smear slides from each major lithology and most minor lithologies are prepared and examined microscopically. Physical disturbance by the drill bit, color, texture (for uncemented lithologies), sedimentary structures, and composition $( \pm 20 \%)$ of the various lithologies are recorded on Core Description Forms (Fig. 3). 


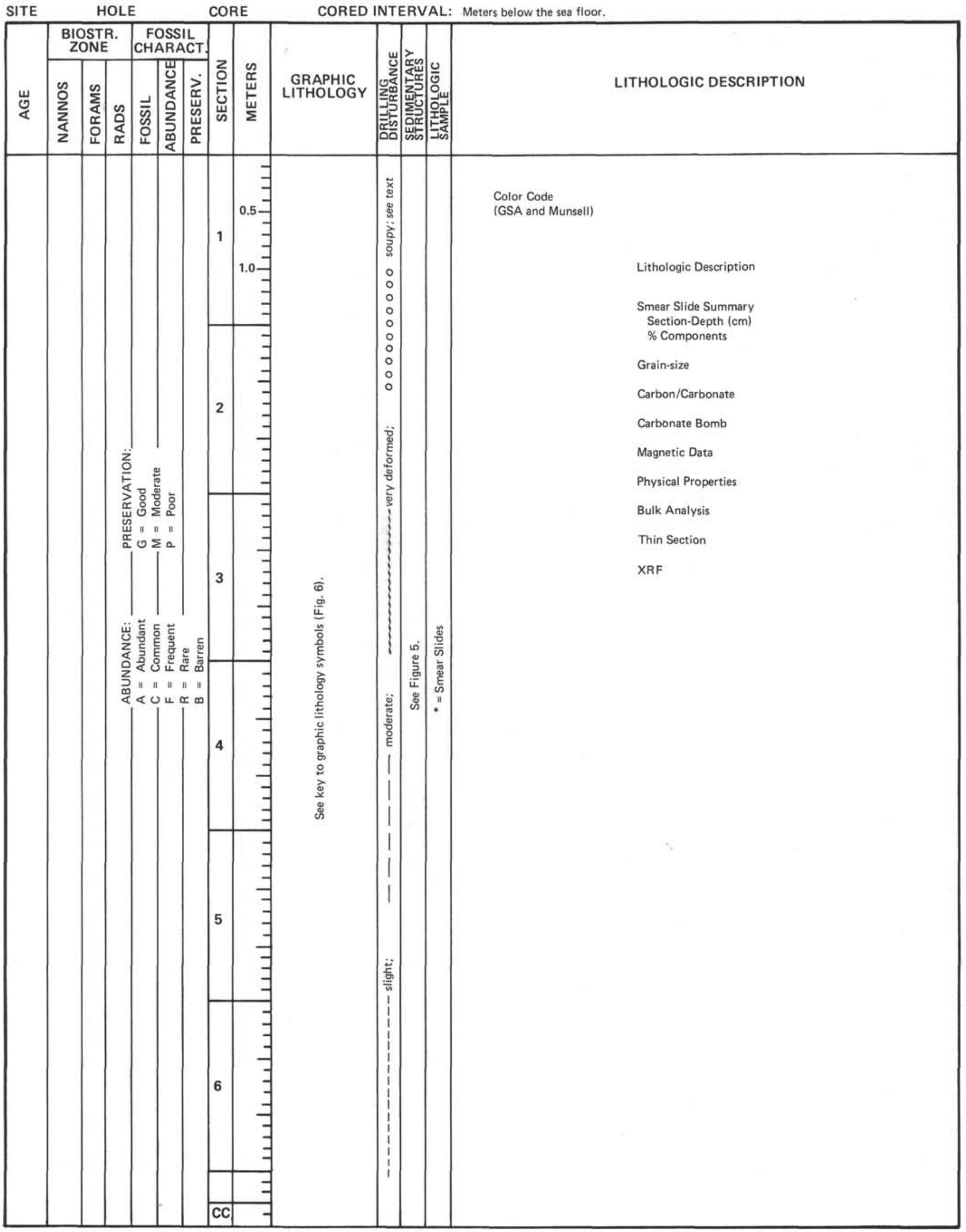

Figure 3. Core Description Form for sediments. 
Basalt and interbedded basalts and volcaniclastics are handled and described in a somewhat different fashion (see Fig. 4 and later text).

After the cores are sampled and described, they are maintained in cold storage aboard Glomar Challenger until they can be transferred to a DSDP repository. During transfer the cores are not maintained at a controlled temperature. All Leg 59 cores are presently stored at the DSDP West Coast Repository (Scripps Institution of Oceanography).

Descriptions of cores, smear slides, and thin sections, and determinations of $\mathrm{CaCO}_{3}$ content (Carbonate Bomb), physical properties, and rock magnetism were made for Leg 59 on board ship. Following the cruise, at shore-based laboratories grain-size analyses, carboncarbonate determinations (DSDP sedimentology laboratory), and X-ray fluorescence (XRF) studies (from the laboratories of John Tarney, Department of Geological Sciences, University of Birmingham) provided data for the Core Descriptions in this volume. These samples, and their location in the cores, are coded on the Core Description Forms; the key to these codes is shown in Figures 3 and 4 .

\section{Procedures Used in the Measurement of Physical- Chemical Properties and in Sediment Analysis}

\section{Physical Properties}

A thorough discussion of procedures used in the measurement of physical properties is given by Boyce (1973); only a brief review is offered here. The physical properties themselves are presented in graphic form and discussed in each site chapter. Explanation of some measuring techniques and data processing follows.

1) Sediment water content $(W)$ is defined as the weight of water in the sediment divided by the weight of the saturated wet sediment.

2) Sediment porosity $(\phi)$ is defined as the volume of pore space divided by the volume of wet-saturated sample and expressed as per cent.

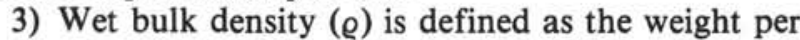
volume in $\mathrm{g} / \mathrm{cm}^{3}$ of the wet-saturated sediment, i.e.,

$$
\varrho=\frac{\text { weight of wet sediment }(\mathrm{g})}{\text { volume of wet sediment }\left(\mathrm{cm}^{3}\right)}
$$

The continuous plots of density (site chapters only) are obtained from the GRAPE results (see the material following), assuming a mean grain density of 2.75 $\mathrm{g} / \mathrm{cm}^{3}$ and a water density of $1.024 \mathrm{~g} / \mathrm{cm}^{3}$. Although the mean grain density assumption resulted in slightly erroneous values for siliceous ooze, it proved quite accurate for the carbonate ooze and volcaniclastic debris that comprised the bulk of the material encountered during drilling in the South Philippine Sea. Based on the same assumption, special "two-minute" GRAPE densities were obtained from the static GRAPE results.

4) Compressional wave velocity. The sonic velocity is obtained by timing a $400-\mathrm{kHz}$ sonic pulse across two transducers with an oscilloscope and measuring the distance across the sample with a dial gage (Hamilton
Frame method). Correction factors for the oscilloscope are given in Table 1. Measurements were made at ambient laboratory pressures and temperatures. Wherever possible, sediment velocities were measured in two orthogonal directions-parallel and perpendicular to the core axis (i.e., in vertical and horizontal directions).

\section{Inorganic Geochemical Measurements}

Aboard ship, analyses for $p \mathrm{H}$, alkalinity, chlorinity, $\mathrm{Ca}^{++}, \mathrm{Mg}^{++}$, and salinity are conducted routinely.

1) $p \mathrm{H}: \mathrm{A}$ flow-through electrode method is used to determine $p \mathrm{H}$; a small portion of unfiltered pore water is passed through a glass capillary electrode.

2) Alkalinity: Alkalinity is measured by a colorimetric titration of a $1-\mathrm{ml}$ aliquot of interstitial water with $0.1 \mathrm{~N} \mathrm{HCl}$, using a methyl red/blue indicator.

Alkalinity $(\mathrm{meq} / \mathrm{kg})=(\mathrm{ml} \mathrm{HCl}$ titrated $) \times$

3) Salinity: Salinity is calculated from the fluid refractive index as measured by a Goldberg optical refractometer, using the ratio

$$
\text { Salinity }(\% 0)=(0.55) \times \Delta \mathrm{N}
$$

where $\Delta \mathrm{N}=$ refraction index difference $\times 10^{4}$. Local surface sea water is regularly examined by each of the above methods for reference.

\section{Organic Geochemical Measurements}

The main geochemical objectives of Leg 59 at each site were to investigate the gas composition of gas-rich sediment intervals, to determine the organic carbon and nitrogen contents of the sediments at selected horizons and to evaluate the origin and maturity of the sedimentary organic matter using the Girdal Rock Eval.

\section{Gas Analyses}

Gaseous hydrocarbons in the recovered cores are monitored, because the prospect of drilling into a hydrocarbon accumulation without riser capability presents a danger to the ship and personnel and poses a threat of widespread pollution from an uncontrollable oil release. It is also possible to deduce information on the biogenic or thermal origin of the gases and on the extent of diagenesis and maturation of the organic matter as well as to distinguish between gases generated in situ and those migrated from other sources. The absence of hydrocarbon gases suggests a lack of sedimentary organic carbon arising from highly oxidizing conditions of deposition, low sediment-accumulation rates, low productivity, or a combination of these three factors.

Gas shows were sampled according to the standard shipboard procedure, that is, by puncturing the core liner and collecting the gas mixture via stopcock into a "Vacutainer." In general, gas sampling was performed very soon after core recovery or division into sections. In some instances an additional sample was taken several minutes afterwards, when further gas shows appeared on standing. 


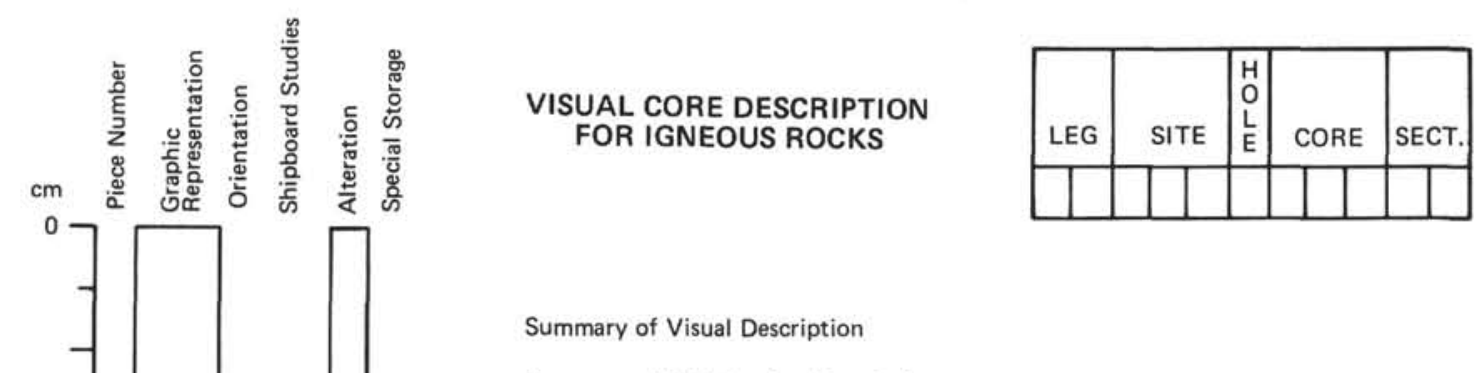

Summary of Thin Section Description 
Table 1. Mean velocity correction factors $\left(K_{\mathrm{p}}\right)$ for each $\mu \mathrm{s} / \mathrm{cm}$ setting on the DSDP Oscilloscope 485.

\begin{tabular}{|c|c|c|c|c|c|c|c|c|}
\hline \multirow{2}{*}{$\begin{array}{c}\text { Thickness of Standards } \\
\mu \mathrm{s} / \mathrm{cm} \text { Settings }\end{array}$} & $2.54 \mathrm{~cm}$ & $5.00 \mathrm{~cm}$ & $2.54 \mathrm{~cm}$ & $5.00 \mathrm{~cm}$ & $2.54 \mathrm{~cm}$ & $5.00 \mathrm{~cm}$ & $2.54 \mathrm{~cm}$ & $5.00 \mathrm{~cm}$ \\
\hline & \multicolumn{2}{|c|}{1.0} & \multicolumn{2}{|c|}{2.0} & \multicolumn{2}{|c|}{5.0} & \multicolumn{2}{|c|}{10.0} \\
\hline Lucite & & & 1.00549 & & 1.00807 & 1.02234 & 1.00660 & 1.02158 \\
\hline Brass & 1.01093 & & 1.01184 & 1.02628 & 1.02050 & 1.02675 & & 1.02466 \\
\hline Aluminum & 1.01877 & & 1.01893 & 1.02374 & 1.02374 & 1.02875 & & \\
\hline Shipboard Mean $\left(K_{\mathrm{p}}\right)$ & 1.01 & 485 & 1.0 & 436 & 1.0 & & 1.0 & 761 \\
\hline
\end{tabular}

The composition of the gas shows was determined by gas chromatographic analysis using Carle 8000 and Hewlett-Packard 5711A instruments. For methane/ ethane analyses, the $10-\mathrm{ft}$ column of the Carle 8000 was held isothermally at $38^{\circ} \mathrm{C}$ with a $\mathrm{He}$ carrier gas $(20 \mathrm{psi}$, $15 \mathrm{ml} / \mathrm{min}$ ). The detection limits of this instrument were calculated as $200 \mathrm{ppm}$ for $\mathrm{CH}_{4}$ and $500 \mathrm{ppm}$ for $\mathrm{C}_{2} \mathrm{H}_{6}$ from calibrations with gas standards. Air, $\mathrm{CO}_{2}$, and $\mathrm{H}_{2} \mathrm{~S}$ were also detected by the Carle $8000 ; 1-\mathrm{ml}$ and $250-\mathrm{ml}$ injections were used for samples and standards, respectively.

$\mathrm{C}_{2}$ to $\mathrm{C}_{5}$ hydrocarbon gases were investigated using the Hewlett-Packard 5711A instrument fitted with dual columns (1/8 in. o.d. $\times 4$-ft Spherosil attached to $1 / 8$ in. o.d. $\times 12$-ft. $20 \%$ OV-101 on Anakrom 100/110AS) and flame ionization detectors. A He carrier (60 psi, 15 $\mathrm{ml} / \mathrm{min}$ ) was used. To enhance sensitivity to other hydrocarbon gases, methane was flushed $\left(-70^{\circ} \mathrm{C}\right)$ through the system for two minutes with $\mathrm{He}$, as other components were condensed in a cooling loop filled with Analabs 60/80 mesh alumina. After flushing, the loop was heated to $85^{\circ} \mathrm{C}$ for $2 \mathrm{~min}$, and the sample was introduced to the gas chromatographic column via a microvalve (Carle 2014). The CG oven was programmed to heat from $60^{\circ}$ to $200^{\circ} \mathrm{C}$ at $4^{\circ}$ or $8^{\circ}$ per min. At $200^{\circ}$, the oven was held isothermally for four min. Peak mensuration was performed by an integrator (Columbia Scientific Instruments Supergrator 1), and the sensitivity and performance of the gas chromatograph was monitored using three different standard mixtures of various normal, branched, and cyclic gaseous alkanes. The detection limits, calculated from the standards, ranged from $0.025 \mathrm{ppm}$ for ethane to $0.007 \mathrm{ppm}$ for 3-methylpentane, assuming a $10-\mathrm{ml}$ sample injection volume. For standards, 1-ml injections were used routinely. Blank analyses always gave three spurious peaks in the $\mathrm{C}_{6}$ region attributable to the Vacutainer septa.

\section{Organic Carbon and Nitrogen Contents}

A fundamental parameter of organic geochemical investigations of sediments is the organic carbon content, because it is related to the amount of organic matter present. In addition, the quantity can be indicative of the depositional environment of the sediment, because the degree of preservation of organic matter is determined by interrelated physical, chemical, and biological factors. The autochthonous generation of organic matter, the allochthonous input of organic matter, the oxicity/anoxicity of the depositional environment, and the sedimentation rate are four major factors that affect the quantity of organic carbon incorporated into sediments. These factors effectively determine the amount of organic material originally present in a sediment and the extent of preservation of that organic material. These factors do not, however, completely determine the final organic carbon content of a sediment, because chemical modification of the organic matter takes place during diagenesis. Postdepositional changes generally influence the nature of the organic matter rather than the quantity present, unless migrational processes occur.

The factors governing the nitrogen content of sediments are less well understood than those controlling the amount of organic carbon present, but, in general, similar criteria apply. The geochemically important biogenic nitrogen compound classes include the amino acids and their proteins and the tetrapyrroles, namely chlorophylls, chlorins, and porphyrins. In addition, recent studies have shown that the majority of the nitrogen content of sediments is contained within polymeric kerogen molecules rather than extractable components. One parameter of immediate use is the $\mathrm{C} / \mathrm{N}$ atomic ratio because high values (e.g., $>40$ ) are characteristic of terrestrial material.

Samples were weighed on a Cahn Electrobalance mounted on a gimbal that has an estimated accuracy of $\pm 0.2 \mathrm{mg}$, depending upon sea conditions. In order to remove inorganic carbonate, each 3-gram sample was heated at $110^{\circ} \mathrm{C}$ for $12 \mathrm{~h}$ and then ground. Concentrated $\mathrm{HCl}$ was added to the sample and the mixture was left to stand for $12 \mathrm{~h}$. Then the sample was rinsed three times with $15 \mathrm{ml}$ of deionized water (to remove traces of $\mathrm{HCl}$ ) and dried at $110^{\circ} \mathrm{C}$.

A Hewlett-Packard 185B instrument was used for the organic carbon and nitrogen analyses, with a $\mathrm{He}$ carrier gas $(60 \mathrm{psi}, 120 \mathrm{ml} / \mathrm{min})$. A small amount of preconditioned catalyst was added to each sample $(25-80 \mathrm{mg})$. Except for the lignite from Hole 451 (Core 56, Section 3 ), all samples were pretreated to remove carbonate. The shore-based analysis of the lignite kerogen concentrate (prepared by flotation on $\mathrm{CCl}_{4}$ ) was carried out using a Perkin-Elmer 240 microanalyzer (School of Chemistry, University of Bristol).

The standard used for calibration was acetamide in quartz sand $(\mathrm{C}=0.056 \%, \mathrm{~N}=0.0737 \%)$. To obtain a more appropriate calibration to determine the organic carbon content of the lignite, the "Rock Eval" standard (No. $27251, \mathrm{C}=5.16 \%$ ) was also used. The calculation of the organic carbon (or nitrogen) content of the sample was made from: 
C (or N) response of sample - response of blank

$$
\begin{aligned}
& \times \frac{\text { Weight of sample }}{\text { Weight of standard }} \\
& \times \% \mathrm{C}(\text { or } \mathrm{N}) \text { response of standard }- \text { response of blank }
\end{aligned}
$$

The precision of peak measurement was estimated to be within $\pm 20 \%$ so that many of the lean samples are accurate to an order of magnitude only. All $\mathrm{C} / \mathrm{N}$ values were calculated as atomic ratios.

\section{Rock Eval}

The Rock Eval is a pyrolysis instrument capable of identifying various characteristics of a source rock. These characteristics include: the terrestrial, marine, or mixed origin of organic matter; the total quantity of oil that it could generate given suitable thermal maturation (petroleum potential); the effect of maturation processes (maturity); and the presence of oil shows within reservoir rocks ("free" hydrocarbons). The investigation of a selection of down-hole samples enables any changes in these parameters to be monitored with increasing depth and hence increasing thermal maturity.

Sedimentary organic matter can be conveniently subdivided into solvent-extractable (lipid), or free, hydrocarbon fractions and solvent-inextractable (kerogen), or bound, hydrocarbon fractions. The proportion of these two fractions of organic matter changes with the thermal maturity of a sediment. The free hydrocarbon content can be enhanced or depleted by migration processes, whereas the bound hydrocarbons represent a potential oil source that will yield petroleum under sufficient thermal treatment. The Rock Eval provides a means of determining the amounts of free ( $S_{1}$-peak) and bound ( $S_{2}$-peak) hydrocarbons in a single analysis. In addition, the $S_{3}$ peak is a measure of the amount of oxygen present in the kerogen, which enables the calculation of $\mathrm{O} / \mathrm{C}$ values. When plotted against the $\mathrm{H} / \mathrm{C}$ ratio, the $\mathrm{O} / \mathrm{C}$ ratio can provide an indication of the source of the organic matter. Kerogens of algal origin (defined as Type I) possess high $\mathrm{H} / \mathrm{C}$ ratios and low $\mathrm{O} / \mathrm{C}$ ratios, whereas those of terrestrial origin (Type III) possess high $\mathrm{O} / \mathrm{C}$ ratios and low $\mathrm{H} / \mathrm{C}$ ratios. Kerogens of intermediate composition also exist (Type II). With increasing maturity the organic matter tends towards lower $\mathrm{H} / \mathrm{C}$ and $\mathrm{O} / \mathrm{C}$ ratios, to a point where the three types are indistinguishable. Type I kerogens are excellent oil source rocks, Type II moderate source rocks and Type III poor source rocks. When data from the Rock Eval are combined with a value of organic carbon, the origin and maturity of the organic matter can be deduced. In addition the temperature of the maximum of the $S_{2}$ peak from the Rock Eval increases with increasing sample maturity.

During Leg 59, all samples were dried at ambient conditions; some were ground prior to analysis. The average sample weight used was $90 \mathrm{mg}$. A detailed account of the operation of the instrument and the principles on which it is based has been published elsewhere
(Espitalie et al., 1977). The standard used for calibration was I.F.P. No. 27251.

\section{Sedimentologic Analyses}

1. Carbonate Analysis. The percentage of $\mathrm{CaCO}_{3}$ was determined on board ship by the Carbonate Bomb technique (Müller and Gastner, 1971). In this simple procedure, a sample is powdered and treated with $\mathrm{HCl}$ in a closed cylinder. Any resulting $\mathrm{CO}_{2}$ pressure is proportional to the $\mathrm{CaCO}_{3}$ content of the sample. Application of the calibration factor to the manometer reading $(\times 100)$ yields the $\mathrm{CaCO}_{3}$ percentage. Error can be as low as $1 \%$ for sediments high in $\mathrm{CaCO}_{3}$, and in general an accuracy of $\sim 2 \%$ to $5 \%$ can be obtained.

2. Carbon-carbonate analysis. Following the cruise, sediment samples were analyzed at the DSDP sediment laboratory on a LECO WR-12 Carbon Analyzer. Sample preparation procedures are identical to those used with the old LECO 70 Analyzer as outlined in Boyce and Bode (1972) and Bode (1973); discussion of the LECO WR-12 Analyzer is in Bode (1973). Accuracy and precision of the results are as follows:

$$
\begin{aligned}
\text { Total carbon } & = \pm 0.3 \% \text { (absolute) } \\
\text { Organic carbon } & = \pm 0.06 \% \text { (absolute) } \\
\mathrm{CaCO}_{3} & = \pm 3.0 \% \text { (absolute) }
\end{aligned}
$$

3. Grain-size analysis. Distribution of sand-size, siltsize, and clay-size particles was determined from $10 \mathrm{~cm}^{3}$ sediment samples at the DSDP sediment laboratory by standard sieve and pipette methods (see Bader, Gerard, et al., 1970, with modified settling times as in Boyce, 1973). Shepard's (1954) sediment textural classification was used in Leg 59 descriptions (Fig. 5). The sand, silt, and clay boundaries are based on the Wentworth (1922)

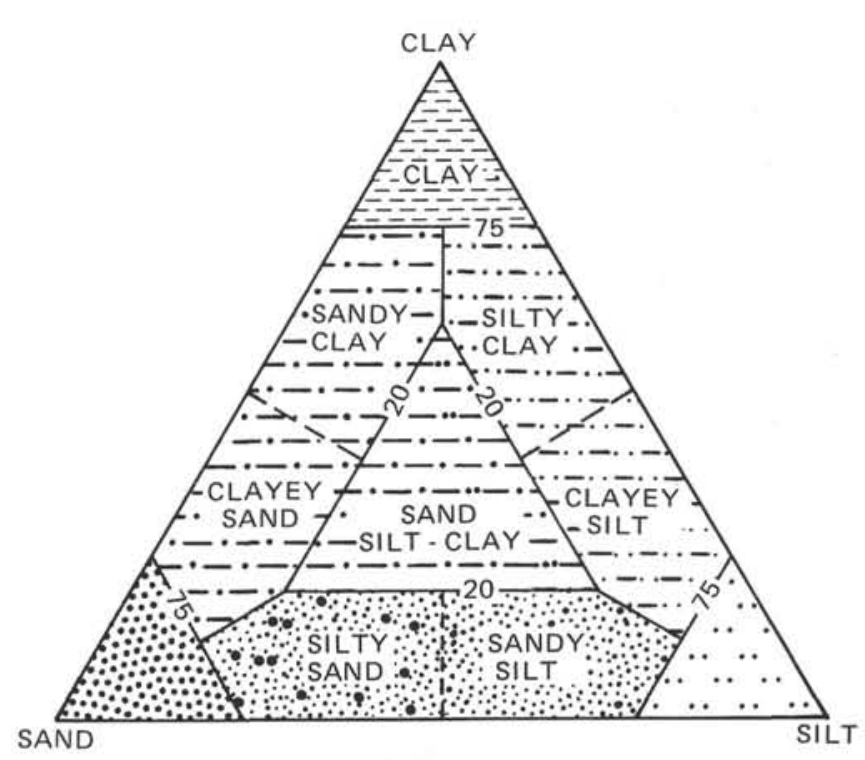

Figure 5. Textural classification of clastic sediments (after Shepard, 1954). 
scale. Thus the particle size of the sand, silt, and clay fraction ranges from $2000 \mu \mathrm{m}$, to $62.5 \mu \mathrm{m}$, to less than $3.91 \mu \mathrm{m}$, respectively.

\section{Sediment Description Conventions}

\section{Sediment Disturbance}

Recovered cores, and particularly the soft sediments, may be extremely disturbed. This mechanical disturbance is the result of the coring technique, which uses a large $25.0-\mathrm{cm}$ diameter bit with a small $6.0-\mathrm{cm}$ diameter opening for the core sample. The following disturbance categories were used for soft and firm sediment. These categories are designated by symbols shown on Figure 4. ----- Slightly deformed: bedding contacts are slightly bent.

- - - Moderately deformed: bedding contacts have undergone extreme bowing.

Very deformed: bedding is completely disturbed, sometimes showing symmetrical diapir-like structure.

○०000000 Soupy: water-saturated intervals have lost all aspects of original bedding.

\section{Sediment Induration}

The determination of induration is highly subjective, but field geologists have successfully made similar distinctions for many years. The criteria of Gealy et al. (1971) were used for calcareous deposits; for other sediments we employed criteria based on subjective estimates or behavior in core cutting.

1) Calcareous sediments

Soft: Oozes have little strength and are readily deformed under the finger or the broad blade of a spatula.

Firm: Chalks are partly indurated oozes; they are friable limestones that are readily deformed under the fingernail or the edge of a spatula blade.

Hard: Cemented rocks are termed limestones.

2) Other sediments

If the material is soft enough for the core to be split with a wire cutter, only the sediment name is used (e.g., silty clay; sand).

If the core has to be cut on the band saw or diamond saw, the suffix "stone" is used (e.g., silty claystone; sandstone).

\section{Sedimentary Structures}

Megascopic sedimentary structures are apparent in many of the cored sediments. These include primary features such as lamination, graded bedding, and bioturbation as well as secondary features such as microfaulting. Where it is reasonably certain that these features are not the product of coring disturbance, they are logged graphically in a separate column on the core description forms (Fig. 3) utilizing the symbols shown in Figure 6.

\section{Color}

Colors of the geologic material were determined with a Munsell or Geological Society of America Rock-Color

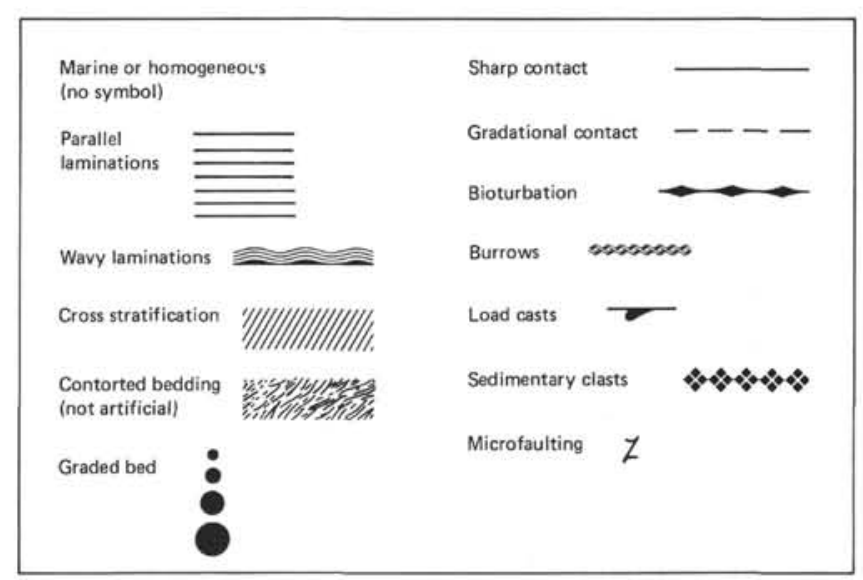

Figure 6. Sedimentary structure symbols.

Chart immediately after the cores were split and while in a wet condition.

\section{Smear Slides}

The lithologic classification of sediments is based on visual estimates of texture and composition in smear slides made on board ship. These estimates are of areal abundances on the slide and may differ somewhat from the more accurate laboratory analyses of grain-size, carbonate content, and mineralogy. Experience has shown that distinctive minor components can be accurately estimated $(\sim 1 \%$ or $2 \%)$, but that an accuracy of $\sim 10 \%$ for major constituents is rarely attained. Carbonate content is especially difficult to estimate in smear slides, as is the amount of clay present.

\section{Sedimentary Lithologic Classification}

The lithologic classification scheme used on Leg 59 is basically that devised by the JOIDES Panel on Sedimentary Petrology and Physical Properties and adopted for use by the JOIDES Planning Committee in March 1974. The classification is descriptive and sedimentrock names are defined solely on the basis of composition and texture, primarily as determined from smear slides, bomb analyses, or under the hand lens or microscope on board ship. The classification is outlined below; symbols utilized to represent the various sediment types on Core Description Forms are shown in Figure 7.

I. Pelagic clay. $>10 \%$ authigenic components

$<30 \%$ siliceous microfossils

$<30 \% \mathrm{CaCO}_{3}$

$<30 \%$ terrigenous components

II. Pelagic siliceous biogenic sediments.

$>30 \%$ siliceous microfossils

$<30 \% \mathrm{CaCO}_{3}$

$<30 \%$ terrigenous components (mud)

Radiolarians dominant: radiolarian ooze (or radiolarite)

Diatoms dominant: diatom ooze (or diatomite)

Sponge spicules dominant: sponge spicule ooze (or spiculite) 
Pelagic

Non-biogenic

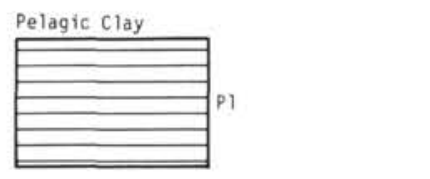

Siliceous Biogenic

Pelagic Siliceous Biogenic - Soft

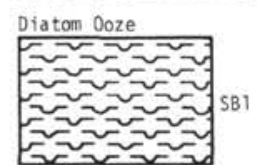

Radiolarian 0oze

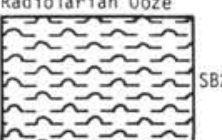

Pelagic Siliceous Biogenic - Hard

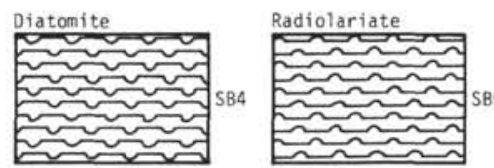

Iransitional Biogenic Siliceous Sediments

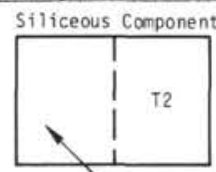

Vertical bar percent

(₹) Designation
for Graphic Log.

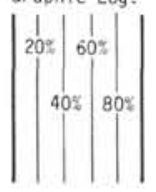

Diatom-Rad or

Siliceous 0oze

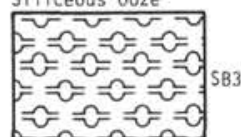

Volcaniclastic Sediments

Volcaniclastic

Breccia

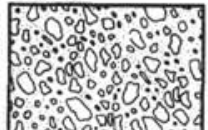

Tuffaceous

Volcaniclastic

Breccia

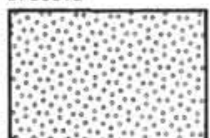

Calcareous Biogenic

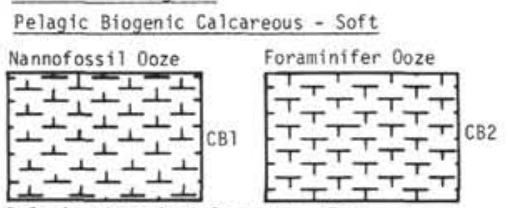

Pelagic Biogenic Calcareous - Firm

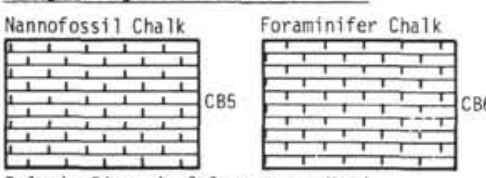

Pelagic Biogenic Calcareous - Hard

Limestone

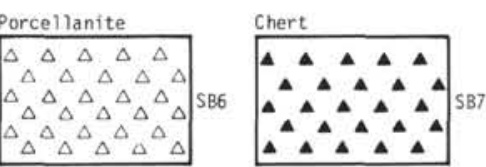

Siliceous Component $>50 \%$

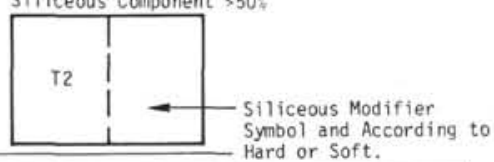
Symbol and Ac
Hard or Soft.

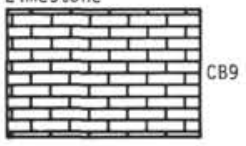

Terrigenous Sediments
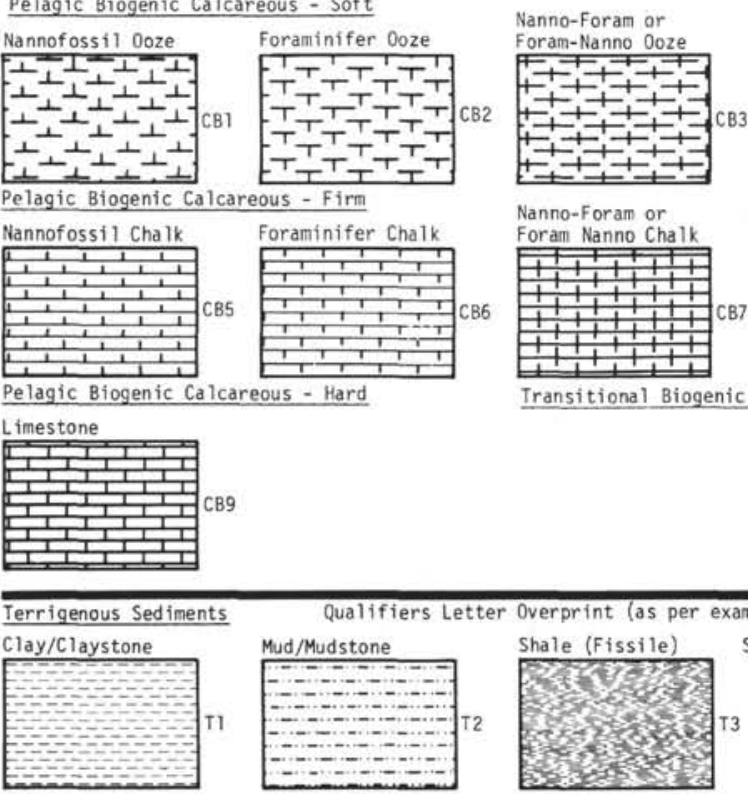

Calcareous 0oze

잉이엉

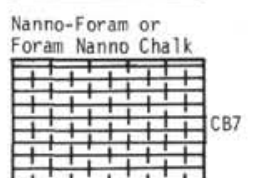

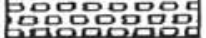

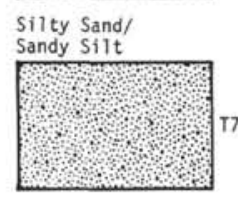

Pyroclastic Tuff

Calcareous Chalk
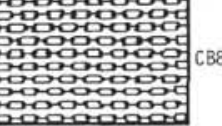

Iransitional Biogenic Calcareous Sediments
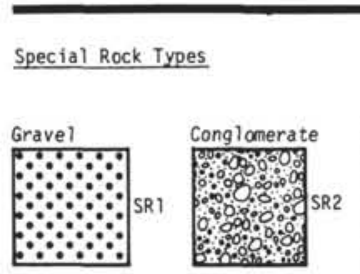

Figure 7. Graphic symbols to accompany the lithologic classification scheme. 
Where uncertain: siliceous (biogenic) ooze (or chert, porcelanite)

When containing $10 \%$ to $30 \% \mathrm{CaCO}_{3}$ : modified by "'nannofossil," "'foraminiferal," "calcareous," "'nannofossil-foraminiferal,", or "foraminiferal-nannofossil," depending upon kind and quantity of $\mathrm{CaCO}_{3}$ component.

III. Transitional biogenic siliceous sediments.

$10 \%$ to $70 \%$ siliceous microfossils

$30 \%$ to $90 \%$ terrigenous components (mud)

$30 \% \mathrm{CaCO}_{3}$

If diatoms < mud: diatomaceous mud (mudstone)

If diatoms > mud: muddy diatom ooze (muddy diatomite)

If $\mathrm{CaCO}_{3}$ is $10 \%$ to $30 \%$ : appropriate qualifier is used (see II).

IV. Pelagic biogenic calcareous sediments.

$>30 \% \mathrm{CaCO}_{3}$

$<30 \%$ terrigenous components

$<30 \%$ siliceous microfossils

Principal components are nannofossils and foraminifers; qualifiers are used as follows:

Foraminifer

$\begin{array}{cl}\frac{\text { Content }}{<10 \%} & \begin{array}{l}\text { Name } \\ \text { nannofossil ooze (chalk, } \\ \text { limestone) }\end{array} \\ 10-25 \% & \text { foraminiferal-nannofossil ooze } \\ 25-50 \% & \text { nannofossil-foraminiferal ooze } \\ <50 \% & \text { foraminiferal ooze }\end{array}$

Calcareous sediments containing $10 \%$ to $30 \%$ siliceous fossils carry the qualifier radiolarian, which is diatomaceous or siliceous, depending upon the identification.

V. Transitional biogenic calcareous sediments.

$>30 \% \mathrm{CaCO}_{3}$

$>30 \%$ terrigenous components

$<30 \%$ siliceous microfossils

If $\mathrm{CaCO}_{3}$ is $30 \%$ to $60 \%$, marly is used as a qualifier:

soft: marly calcareous (or nannofossil, etc.) ooze

firm: marly chalk (or marly nannofossil chalk, etc.)

hard: marly limestone (or marly nannofossil limestone, etc.)

If $\mathrm{CaCO}_{3}$ is $60 \%$ :

soft: calcareous (or nannofossil, etc.) ooze

firm: chalk (or nannofossil chalk, etc.)

hard: limestone (or nannofossil limestone, etc.)

(NOTE: Sediments containing $10 \%$ to $30 \%$

$\mathrm{CaCO}_{3}$ fall in other classes, where they are described by the adjectives such as "calcareous," "nannofossil," etc.)

VI. Terrigenous sediments.

$>30 \%$ terrigenous components

$<30 \% \mathrm{CaCO}_{3}$

$<10 \%$ siliceous microfossils

$<10 \%$ authigenic components

Sediments in this category are subdivided into textural groups on the basis of the relative propor- tions of three grain-size components, i.e., sand, silt, and clay. The size limits are those defined by Wentworth (1922). The textural classification is according to the triangular diagram shown in Figure 5. The suffix "stone" is used to indicate hard or consolidated equivalents of the unconsolidated sediments.

If $\mathrm{CaCO}_{3}$ is $10 \%$ to $30 \%$ : "calcareous," "nannofossil," etc. are used as qualifiers.

Other qualifiers (e.g., feldspathic, glauconitic, tuffaceous, etc.) are used for components $>10 \%$.

VII. Volcaniclastic sediments.

Sites $447,448,450$, and 451 yielded considerable thicknesses of bedded volcaniclastic sediments and rocks. For the most part these materials are included within oceanic sequences of pelagic sediments and were deposited in a deep-water environment. In general they occur as: (1) volcanogenic debris directly supplied from near and/or far sources; (2) penecontemporaneous volcanogenic turbidites derived from arc activity; (3) epiclastic turbidites derived from arc erosion; and (4) volcanogenic debris consisting of clasts of basin basalts presumably derived from erosion of tectonic breccias. These genetically different deposits may or may not be associated with normal deep-sea sediments, and the four types may be mixed together in various combinations.

Some preexisting classifications have genetic connotations; others are based on characteristics of subaerial deposits. Rather than following preexisting classifications, the scientific team of Leg 59 used the nongenetic, descriptive textural classification shown in Table 2, devised by Rodolfo and Sartori, two of the Leg 59 sedimentologists.

\section{Biostratigraphy}

Zonal schemes used by Leg 59 shipboard paleontologists are, for foraminifers, Blow (1969); for nannofossils, Martini (1971); for Quaternary radiolarians, Nigrini (1971) and Oligocene to Pliocene radiolarians, Riedel and Sanfilippo (1978) (Table 3). Wherever possible, zone boundaries are based upon the nominate species of the original zone definition. However, in those cases where, for whatever reason, the nominate species were absent, we have utilized other species, ranges of which are reasonably well known from areas where they occur together with the nominate species. In several instances, in the absence of any diagnostic species, zonal boundaries could not be recognized at all.

\section{Igneous Rock Description Conventions}

\section{Visual Core Description Forms}

Visual Core Description Forms for igneous and metamorphic rocks are not the same as the ones used for sediments. Representation of igneous rocks on core forms comparable to those for sediments is too compressed to provide adequate information for rock sampling. Consequently, the Visual Core Description Form shown in Figure 4 is used to permit more complete 
Table 2. Classification of volcaniclastic sediments.

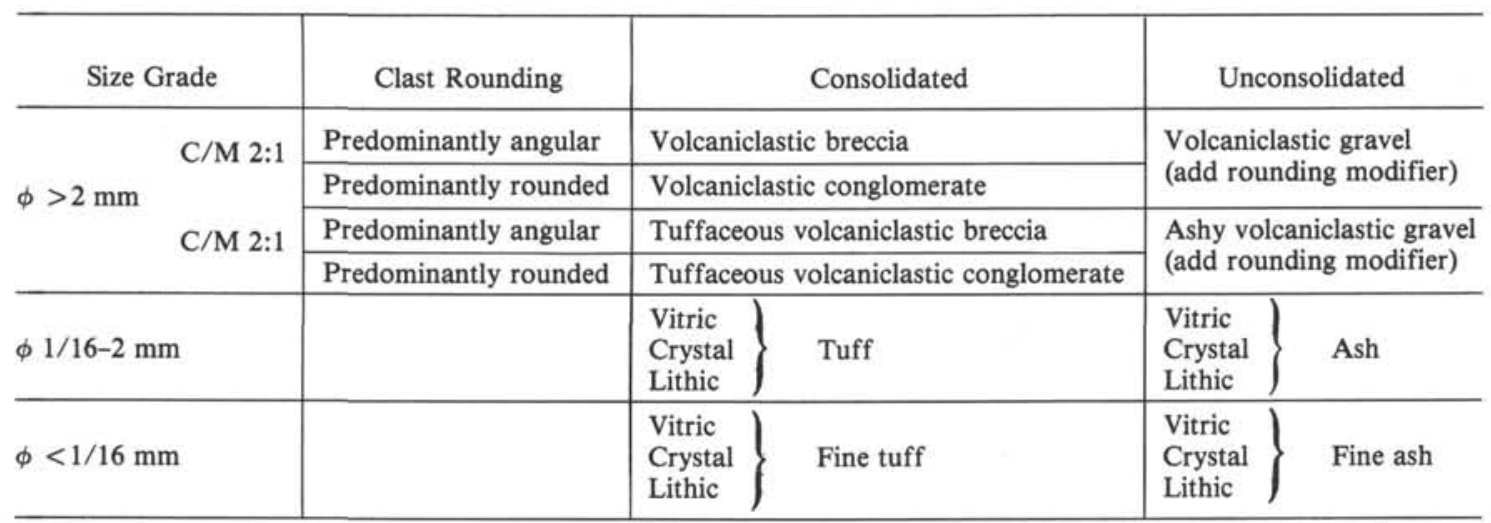

Table 3. Biostratigraphic zonal schemes used by Leg 59 shipboard paleontologists.

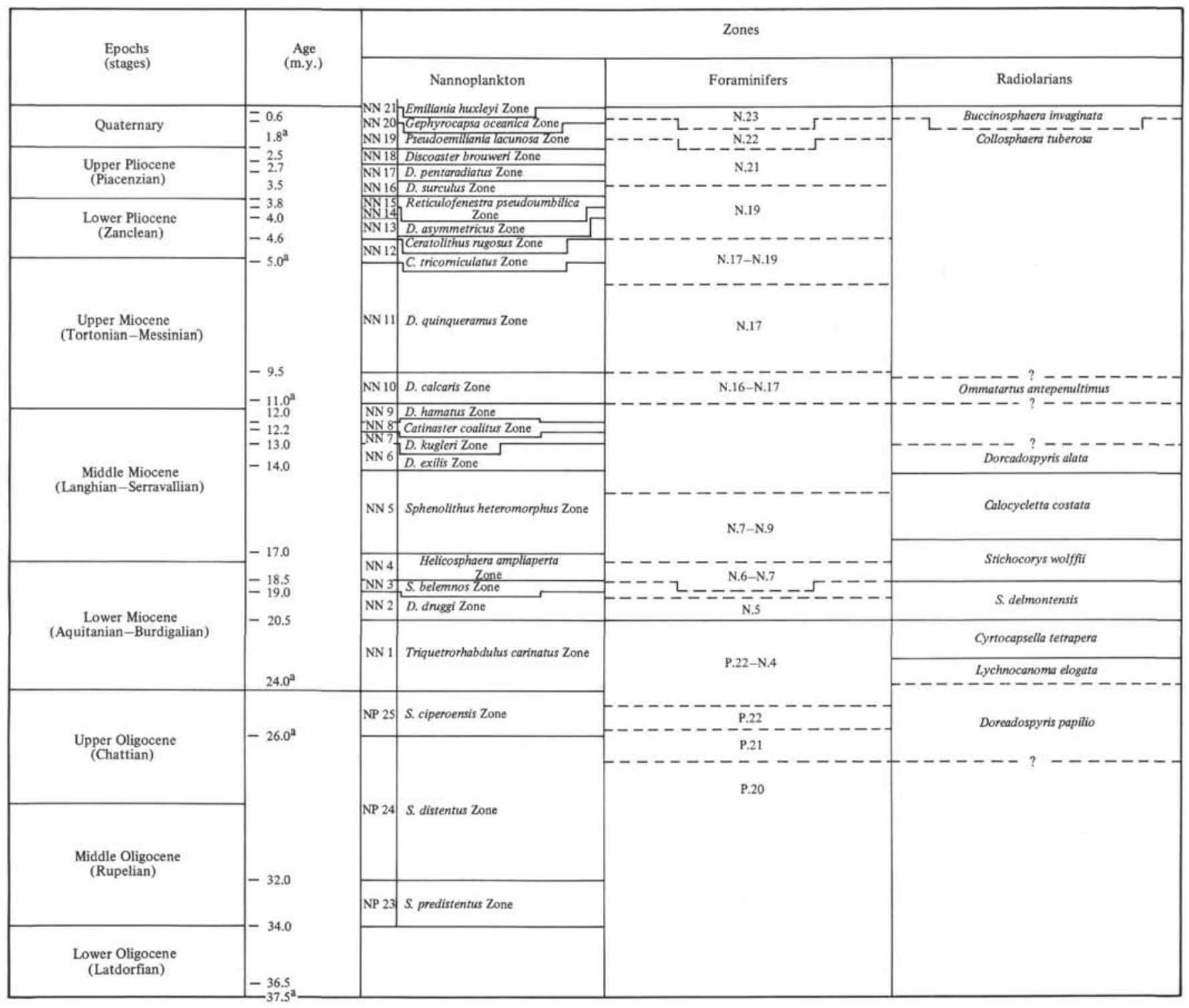

Note: Uncertainties and lack of foraminiferal and radiolarian zones are due to barren intervals.

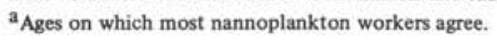


graphic representation. Each of these forms covers one 1.5 -meter section. All chemical, physical property, and magnetic data, as well as summary hand-specimen and thin-section descriptions, are presented for each section.

Using a rock saw, basalt cores were split into archive and working halves. The latter were described and sampled on board ship. On the core forms, the left box is a visual representation of the working half. Two closely spaced horizontal lines in this column indicate the location of styrofoam spacers taped between basalt pieces inside the liner. Each piece is numbered sequentially from the top of each section, beginning with the number 1; pieces are labeled on the rounded, not the sawed surface. Pieces that could be fit together before splitting are given the same number but are lettered separately and consecutively as 1A, 1B, 1C, etc. Spacers are placed between pieces with different numbers, but not between those with different letters and the same number. In general, insertion of spacers represents a drilling gap (no recovery) across which rock-piece shapes or lithologies cannot be matched. All pieces that are cylindrical and longer than the liner diameter have orientation arrows pointing up, both on the archive and working halves. Systematic procedures were adopted to ensure that uniform orientation was preserved through every step of the sawing and labeling process. All orientable pieces are indicated by upward-pointing arrows to the right of the graphic representation on the description forms. Because the pieces were rotated during drilling, it is not possible to sample for declination studies.

Samples were taken for various measurements on board ship as well as later on shore. The type of measurement and approximate location are indicated in the column headed "Shipboard Studies" using the following codes:

$$
\begin{aligned}
\mathrm{X}= & \mathrm{X} \text {-ray fluorescence (these data were sup- } \\
& \text { plied by the laboratories of John Tarney, } \\
& \begin{array}{l}
\text { Department of Geological Sciences, Uni- } \\
\text { versity of Birmingham) }
\end{array} \\
\mathrm{M}= & \text { magnetics measurement } \\
\mathrm{T}= & \text { thin section } \\
\mathrm{P}= & \text { physical-properties measurements }
\end{aligned}
$$

The state of alteration is shown in the column labeled "Alteration" (see Fig. 4).

In some cases, a code on the core form may indicate that samples were taken at levels or intervals in the core for X, M, T, or P studies, but the results are not shown under the description half of the core form. In these instances, the researcher did not report results.

Most of the basalts cored on Leg 59 could be identified as (1) simple flows, (2) pillow lava flows, or (3) pillowed massive flows composed of upper pillow lava underlain by a massive flow. Briefly, the distinction is:

1) Massive basalt flows vary from $75 \%$ to $100 \%$ crystalline; textures range from intersertal through intergranular to strongly ophitic, fine-grained to doleritic. The flows are from 2 to 9.5 meters thick.

2) Pillow lava flows most commonly have prominent, fresh quenched rims that grade from glassy through variolitic through hyalopilitic zones toward the pillow interior. Cores are fine-grained, intersertal to ophitic; except in large pillows they are less than $75 \%$ crystalline. Phyric lavas commonly show gravity settling of phenocrysts, notably olivine. Interpillow glass breccias are common, fresh or altered, veined and cemented with carbonate and zeolites. Pillow flows range from 7 to 35 meters thick; individual pillows are from 0.25 to 1.5 meters in size.

3) Pillowed massive flows are, as the name suggests, a combination of the above two. An upper pillow lava layer, 1 to 12 meters thick, grades down into a massive flow base, 1 to 7.5 meters thick; the pillowed portion averages $60 \%$ of each unit. The rhythmic succession of these units is a striking feature of the basalts from Hole $447 \mathrm{~A}$, where 11 of the 18 cooling units are of this compound type, and each appears to be a single eruptive unit.

In Holes $448 \mathrm{~A}$ and 450 , intrusive igneous rocks were recognized by criteria detailed in Chapters 3 and 5 of this volume, respectively.

Terminology used to classify volcanic rocks is based upon (1) mineralogy of the phenocrysts visible in hand specimens or thin section and (2) the chemical criteria determined by X-ray fluorescence, for example, an olivine-plagioclase-phyric-tholeiitic basalt. Intrusive rock terms also follow both mineralogy and X-ray fluorescence criteria. Relatively few rock terms are used in this volume; most of the rocks are indistinguishable from mid-ocean ridge (MOR) tholeiites, arc tholeiites, calc-alkalic basalts and basaltic andesites, and plutonic equivalents of these rocks. The chemical and mineralogical criteria by which these names are applied are covered in Carmichael et al. (1974).

Metamorphic rocks of Sites 448 and 451 are very lowgrade rocks resulting from hydrothermal reaction between sea water and warm rock. Classification schemes are not feasible for these rocks, because existent schemes are based upon zeolite and clay X-ray identification, and these facilities were not available on Leg 59 .

Petrographic terminology has been made as uniform and simple as possible; in all cases, the definitions adhere to those given in the American Geological Institute Glossary of Geology.

\section{Paleomagnetic Measurements}

Wherever possible, sediments and igneous rocks were sampled in order to determine the paleoinclination and thus the paleolatitude of the sediments and rocks composing the cored section. In most cases, a $2.5-\mathrm{cm}$ diameter cylindrical sample was collected from undisturbed sediment sections (with the exception of volcaniclastic breccias and conglomerates) and from the least-altered igneous units. On one occasion, a breccia unit was sampled in order to determine if it had been reheated and thus remagnetized.

The procedure followed was to scribe an arrow marking the up direction on an individual core segment, parallel to the axis of the core (vertical core margin). The segment was removed from the core liner and a oneinch $(2.5 \mathrm{~cm})$ cylindrical sample was cut using a drill press; the cylinder was then cut to an inch in length. 
The samples were then measured on the Glomar Challenger using a Digico magnetometer. Only a few samples were demagnetized on board, using the Schonstedt AC Specimen Demagnetizer. All of the samples were subsequently remeasured on a Schonstedt digital spinner magnetometer and/or a ScT cryogenic magnetometer in the Paleomagnetism Laboratory of the Hawaii Institute of Geophysics (HIG). The igneous samples were demagnetized at HIG using the Schonstedt AC Specimen Demagnetizer in a 3-axis demagnetization procedure. Likewise, the sediments were demagnetized at HIG in a 4-axis tumbler in a doubly shielded mumetal room (ambient field less than 100 gammas). The peak alternating field used for demagnetization of the sediments was $400 \mathrm{Oe}$ and $1000 \mathrm{Oe}$ for the basalts. Curie temperature analyses also were made on a horizon Curie balance at HIG and susceptibilities measured on Soiltest susceptibility bridges.

\section{REFERENCES}

Bader, R. G., Gerard, R. D., et al., 1970. Appendix III: Shore-based laboratory procedures. In Bader, R. G., Gerard, R. D., et al., Init. Repts. DSDP, 4: Washington (U.S. Govt. Printing Office), 745-753.

Blow, W. H., 1969. Late middle Eocene planktonic foraminiferal biostratigraphy. In Brönniman, P., and Renz, H. H. (Eds.), Proc. 1st Internatl. Conf. Plankt. Microfossils, Vol. 1: Leiden (E. J. Brill), 199.

Bode, G. W., 1973. Carbon and carbonate analyses-Leg 18. In Kulm, L. D., von Huene, R., et al., 1973. Init. Repts. DSDP, 18: Washington (U.S. Govt. Printing Office), 1069-1076.
Boyce, R. E., 1973. Physical properties-methods. In Edgar, N. T., Saunders, J. B., et al., Init. Repts. DSDP, 15: Washington (U.S. Govt. Printing Office), 1115-1127.

Boyce, R. E., and Bode, G. W., 1972. Carbon and carbonate analyses, Leg 9. In Hays, J. D., et al., Init. Repts. DSDP, 9: Washington (U.S. Govt. Printing Office), 797-816.

Carmichael, I. S. E., Turner, F. J., and Verhoogen, J., 1974. Igneous Petrology: New York (McGraw-Hill).

Espitalié, J., Laporte, L. J., Madec, M., et al., 1977. Methode rapide de caracterisation des roches meres, de leur potentiel petrolier et de leur degre d'evolution. Rev. Inst. Franc. Petrole, 32:32-42.

Gealy, E. L., Winterer, E. L., and Moberly, R., 1971. Methods, conventions and general observations. In Winterer, E. L., Riedel, W. R. et al., Init. Repts. DSDP, 7, Pt. 1: Washington (U.S. Govt. Printing Office), 9-26.

Martini, E., 1971. Standard Tertiary and Quaternary calcareous nannoplankton zonation. Proc. 2nd Plankt. Conf. Roma 1970, Vol. 2: 739-785.

Matthews, T., 1939. Tables of the Velocity of Sound in Pure Water and Sea Water for Use in Echo Sounding and Sound Ranging: London (Admiralty Hydrographic Department).

Müller, G., and Gastner, M., 1971. The "Karbonate Bomb," a simple device for determination of the carbonate content in sediments, soils and other materials. Neues Jahrb. Mineral. Abhandl. 10:466-469.

Nigrini, C. A., 1971. Radiolarian zones in the Quaternary of the Equatorial Pacific Ocean. In Funnell, B. M., and Riedel, W. R. (Eds.), The Micropaleontology of Oceans: Cambridge, England (Cambridge University Press), pp. 443-461.

Riedel, W. R., and Sanfilippo, A., 1978. Stratigraphy and evolution of tropical Cenozoic radiolarians. Micropaleontology, 24:61-96.

Shepard, F. P., 1954. Nomenclature based on sand-silt-clay ratios. J. Sediment. Petrol., 24:151-158.

Wentworth, C. K., 1922. A scale of grade and class terms of clastic sediments. J. Geol., 30:377.

Wentworth, C. K., and Williams, H., 1932. The classification and terminology of the pyroclastic rocks. Rept. Comm. Sedimentation Bull. Nat. Res. Covnc., No. 80:10-53. 